\title{
Studies on the Taxonomy of the Myxobacterales
}

\author{
III. Chondromyces and Stigmatella
}

\author{
HOWARD D. McCURDY \\ Department of Biology, University of Windsor, Windsor, Ontario
}

\begin{abstract}
Classification of the species of the genus Chondromyces Berkeley and Curtis is considered in light of the proposal that the genus be divided into two genera: Stigmatella Berkeley and Curtis (family Cystobacteraceae), with tapered vegetative cells and encapsulated myxospores (microcysts); and Chondromyces (family Polyangiaceae), with cylindrical vegetative cells and similar myxospores. The latter genus, as redefined, would include Chondromyces crocatus (the type species), Chondromyces apiculatus, Chondromyces pediculatus, Chondromyces catenulatus, and Chondromyces lanuginosus. Two species are recognized as belonging to the genus Stigmatella: Stigmatella aurantiaca (the type species) and Stigmatella erecta.
\end{abstract}

In a previous paper (14), the family Polyangiaceae Jahn was redefined to include only those sporangial myxobacters with cylindrical vegetative cells and similar myxospores. Sporangium-forming myxobacters with tapered vegetative cells were placed in a new family, Cystobacteraceae. It has been noted $(12,13,15,17)$ that the organisms presently placed in the genus Chondromyces Berkeley and Curtis (Bergey's Manual, 7th ed., p. 854-891) include organisms of both types. It was suggested that Chondromyces (family Polyangiaceae; reference 14) be retained for those with cylindrical cells (13). Chondromyces aurantiacus (Berkeley and Curtis) Thaxter and Chondromyces brunneus Krzemieniewska and Krzemieniewski, having tapered cells, were placed in the genus Stigmatella Berkeley and Curtis (family Cystobacteraceae), the type species of which is Stigmatella aurantiaca Berkeley and Curtis.

The present paper is concerned with the classification of five species of Chondromyces which were not attended to in the above mentioned considerations. The relationship of the genus Synangium Jahn to Chondromyces is also discussed.

\section{MATERIALS AND METHODS}

Cultures and specimens. The media and procedures referred to here were described in detail elsewhere (13).

The following were organisms examined in pure culture (strain designations beginning with $\mathrm{M}$ are those of the University of Windsor; ATCC strains are from the American Type Culture Collection): Chondromyces crocatus [M38(ATCC 25193), M204, M120]; Chondromyces apiculatus (M6, M32); Chondromyces pediculatus (M118); Stigmatella aurantiaca [M340, M341, "cylindrica" M343, "media" M84, M88, M15 (ATCC 25190), M34]; Stigmatella erecta [M26 (ATCC 25191), M27 (ATCC 25192), M162].

The following were specimens from the Thaxter collection, Farlow Herbarium, Harvard University: $S$. aurantiaca (acc. no. 4473-4479); C. apiculatus (acc. no. $4471,4480-83$; type $=4481)$; Chondromyces catenulatus (acc. no. $4517=$ type, 4518, 3405); $C$. crocatus (acc. no. 4469, 4470, 4484-86, 2466, 6055, $5168,601=$ neotype); Chondromyces thaxteri (Chondromyces lanuginosus; acc. no. 4494 collected by J. H. Faull); Chondromyces sessilis (acc. no. $4505=$ type); C. pediculatus (acc. no. $4524,4525=$ type); and Chondromyces erectus (Podangium erectum; acc. no. 4560).

\section{RESULTS AND DISCUSSION}

For the purposes of this study, a total of 16 pure cultures were identified as belonging to the genus Chondromyces Berkeley and Curtis according to Bergey's Manual (7th ed., p. $854-891$ ), by reference to the original literature and when possible by comparison with herbarium specimens. Those identified as $C$. apiculatus (Fig. 6 and 7) and $C$. pediculatus (Fig. 8 and 9) resembled C. crocatus (Fig. 1-3) in having cylindrical vegetative cells and myxospores of similar morphology. Furthermore, the herbarium specimens of $C$. catenulatus (Fig. 4 and 5), C. lanuginosus (C. thaxteri; Fig. 10), 


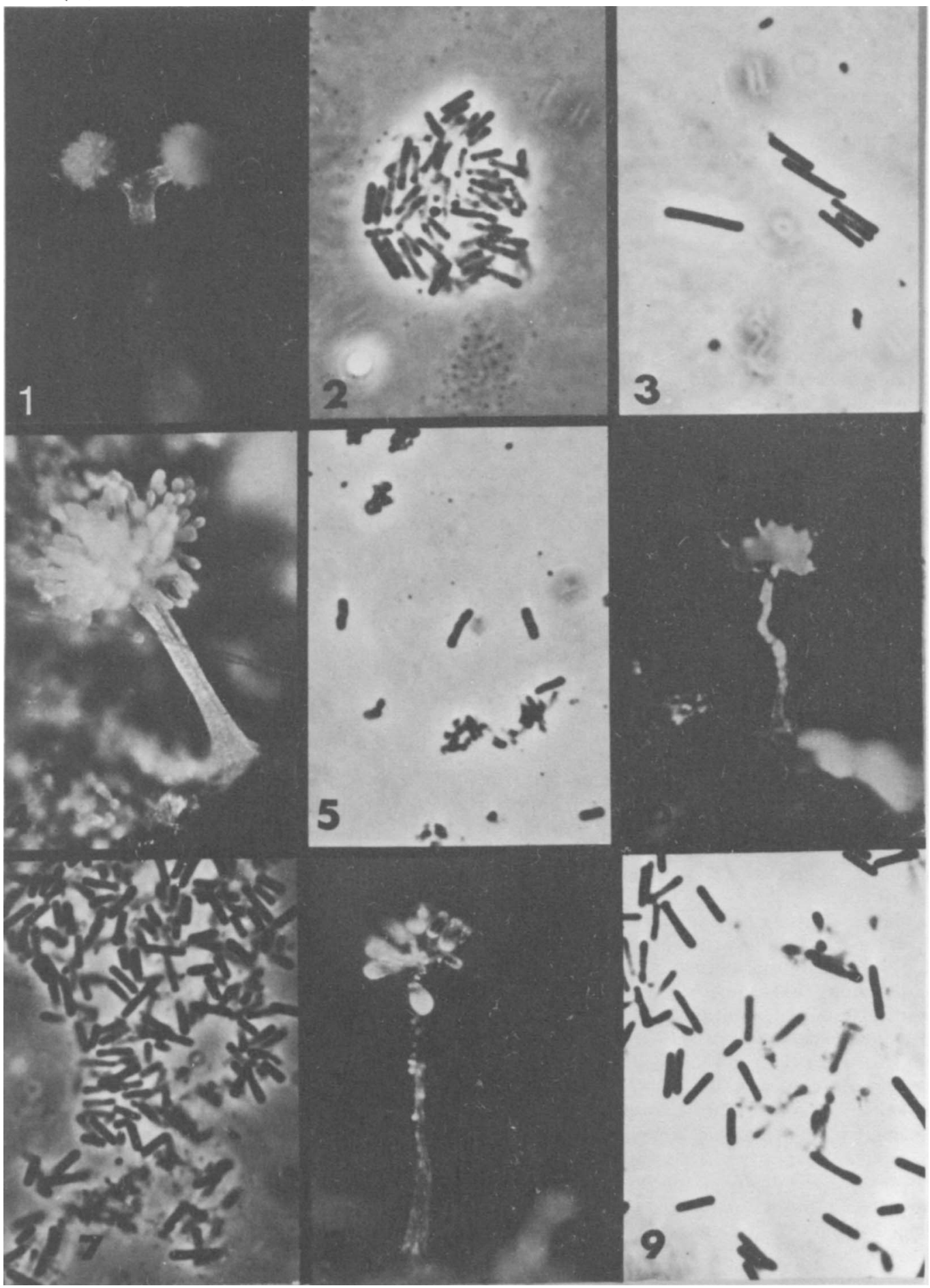

Fig. 1. Chondromyces crocatus, fruiting body. $\times 90$. Fig. 2. Chondromyces crocatus, myxospores. $\times 1,300$ Fig. 3. Chondromyces crocatus, vegetative cells. $\times 1,300$. Fig. 4. Chondromyces catenulatus, fruiting body. $\times 120$. Fig. 5. Chondromyces catenulatus, myxospores. $\times 1,200$. Fig. 6 . Chondromyces apiculatus, fruiting body. $\times 100$. Fig. 7. Chondromyces apiculatus, myxospores. $\times 1,300$. Fig. 8 . Chondromyces pediculatus, fruiting body. $\times 90$. Fig. 9. Chondromycies pediculatus, myxospores. $\times 1,300$. 
and C. sessilis (Fig. 11a, 11b, and 12) were also found to have Chondromyces-type resting cells.

The remaining isolates were members of the genus Stigmatella Berkeley and Curtis. That is, they had tapered vegetative cells and muchshortened, phase-dense or refractile, rigid myxospores (microcysts).

As will be noted by an examination of Table 1, the morphological differences between Stigmatella and Chondromyces are correlated with a number of cultural and biochemical differences, although within the two groups the cultural and biochemical characteristics are rather uniform. As a consequence, morphological characteristics remain of primary importance in distinguishing species.

Chondromyces. Before giving a detailed consideration of the characteristics of the species of Chondromyces, it is necessary to consider the genus Synangium Jahn and its relationship to Chondromyces.

Thaxter (21) described an organism whose irregular sporangia were arranged in sessile rosettes or tufts, which he named $C$. sessilis. Kofler (7) later reported a stalked organism, $C$. lanuginosus, in which the sporangia were fused in the form of discoid or spherical clusters with each sporangium bearing an apical tuft of hairs. Shortly thereafter, Faull (4) gave the name $C$. thaxteri to what was undoubtedly the same organism. Jahn (5), however, recognized all three as distinct species and erected the new genus Synangium to contain them. Krzemieniewska and Krzemieniewski (11), treating Jahn's species as mere varieties, subsequently concluded that there was but one species, Synangium sessile.

A careful comparison of Thaxter's description of $C$. sessilis with those of Faull's and Kofler's organisms does not at all suggest the conclusion that they are identical. On the contrary, our observations of $C$. lanuginosus (= Synangium lanuginosus $=C$. thaxteri ; Fig. 10) and $C$. sessilis (Fig. 11a, 11b) from the Thaxter collection confirms that they are not at all alike. From the author's observations of the specimens of $C$. sessilis which were available (Thaxter apparently observed it only once), this organism, although undoubtedly a chondromycete, should not have been regarded as a new species. Indeed, it might well be a variant of any of the other recognized species of Chondromyces.

On the other hand, C. lanuginosus is certainly a distinct species. The question is whether it is necessary to assign it to a separate genus. Its most distinctive characteristic is the fusion of its sporangia. Both Kofler and Faull remarked on its close resemblance to C. apiculatus. Faull, after a careful study of the ontogeny of the fruiting bodies of $C$. lanuginosus, concluded that the fruiting bodies differed from those of C. apiculatus only in the final stages of development. A close relationship between the two is also suggested by the not infrequent occurrence in C. apiculatus of fruiting bodies with fused sporangia. We agree with Faull, therefore, that the genus Chondromyces constitutes a close evolutionary series in which $C$. lanuginosus, although undoubtedly the most advanced species, is not sufficiently different from the other species to warrant placing it in a separate genus.

Chondromyces Berkeley and Curtis 1874,64 .

(Objective synonym: Myxobotrys Zukal 1896, 346.)

Vegetative cells are cylindrical, untapered rods with bluntly rounded ends.

Sporangia borne singly or in clusters on simple or branched stalks.

Myxospores lack capsules and resemble vegetative rods.

Vegetative swarms etch, erode, and penetrate agar media. Vegetative slime does not adsorb Congo red dye.

Aerobic.

Temperature range, 18 to $37 \mathrm{C}$; optimum 28 to $30 \mathrm{C}$.

Guanine plus cytosine content of species examined is 69 to 70 moles per cent by $T_{m}$ determinations.

Type species: Chondromyces crocatus Berkeley and Curtis 1874, 64.

Descriptions of Species of Chondromyces

Chondromyces crocatus Berkeley and Curtis 1857 and 1874,64. (See reference 1, Fig. 70a and 313.)

(Objective synonym: Myxobotrys variabilis Zukal 1896, 340.)

Vegetative cells (Fig. 3) cylindrical with blunt, rounded ends, 1.1 to $1.4 \mu \mathrm{m}$ by 3 to 12 $\mu \mathrm{m}$.

Sporangia broadly spindle-shaped, conical, or nearly spherical, 10 to $25 \mu \mathrm{m}$ by 15 to 30 $\mu \mathrm{m}$, straw-colored initially, finally becoming golden-yellow or orange. Sporangia borne in spherical clusters on usually branched stalks up to $700 \mu \mathrm{m}$ or more in height (Fig. 1). Stalks orange to brown, striated, often spirally twisted, tunneled internally with few cells within. Irregular forms with ramifying branches and few sporangia or with secondary fruiting structures arising from sporangia germinating in situ may be observed in culture. 


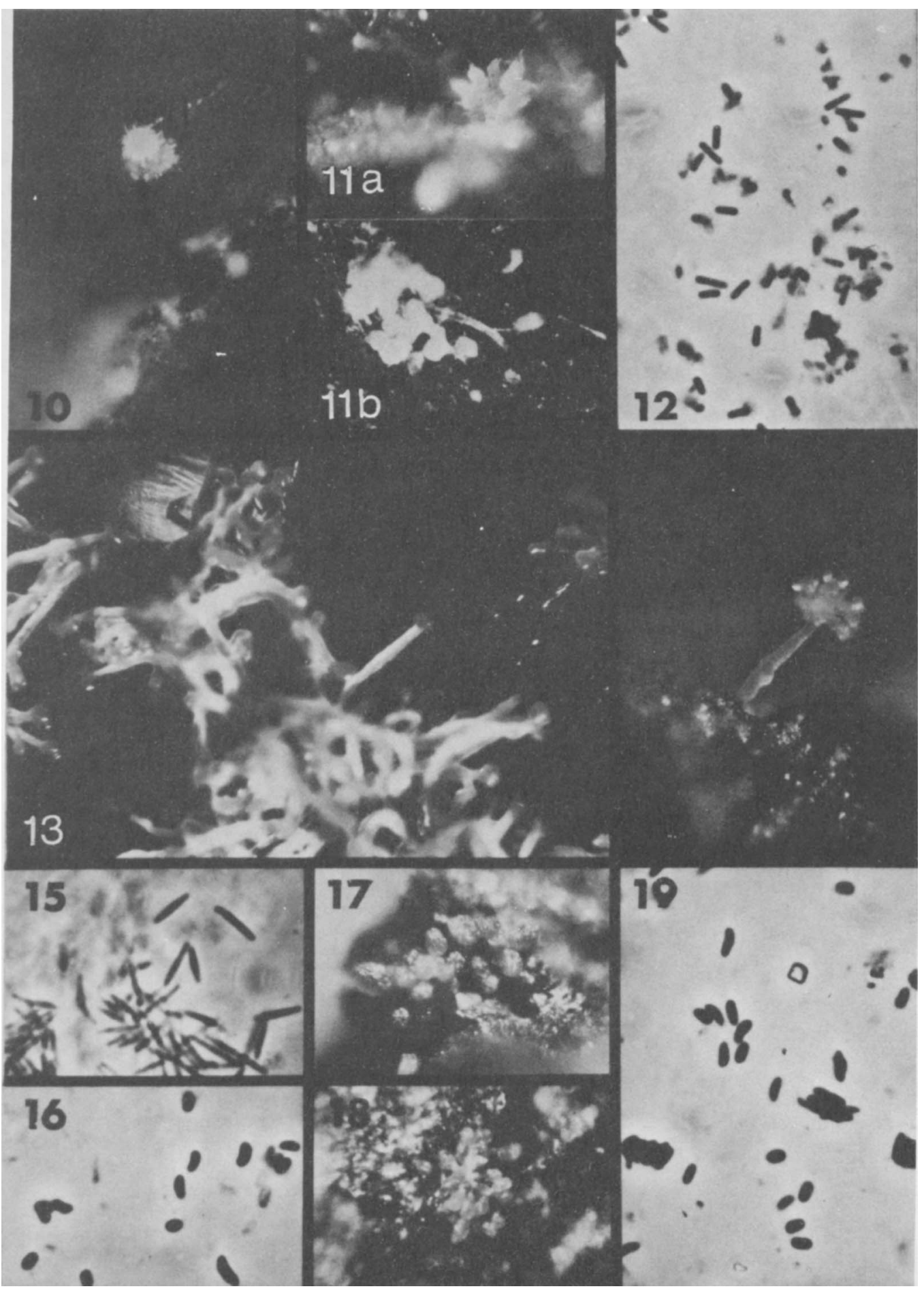

Fig. 10. Chondromyces lanuginosus, fruiting body. $\times 120$. Fig. 11. Chondromyces sessile, fruiting bodies. $\times 120$. Fig. 12. Chondromyces sessile, myxospores. $\times 1,100$. Fig. 13. Stigmatella aurantiaca, fruiting bodies on agar. $\times 100$. Fig. 14. Stigmatella aurantiaca, fruiting body on bark. $\times 90$. Fig. 15 . Stigmatella aurantiaca, vegetative cells. $\times 1,200$. Fig. 16. Stigmatella aurantiaca, microcysts. $\times 1,400$. Fig. 17. M 162 sporangia on bark. $\times 100$. Fig. 18. Podangium erectum herbarium specimen on bark. $\times 100$. Fig. 19. Stigmatella erecta microcysts. $\times 1,300$. 
TABLE 1. Physiological characteristics of isolates

\begin{tabular}{|c|c|c|c|c|c|c|c|c|}
\hline Organism & $\begin{array}{l}\text { Growth } \\
\text { medium }\end{array}$ & $\begin{array}{l}\text { Liquid } \\
\text { culture }\end{array}$ & $\begin{array}{c}\text { Agar } \\
\text { etched }\end{array}$ & $\begin{array}{c}\text { Congo } \\
\text { red }\end{array}$ & $\begin{array}{c}\text { Aescu- } \\
\text { lin }\end{array}$ & Urease & $\begin{array}{l}\text { Neo- } \\
\text { mycin }\end{array}$ & $\begin{array}{l}\text { Kana- } \\
\text { mycin }\end{array}$ \\
\hline Stigmatella aurantiaca M341 & $\mathrm{Sp}$ & + & - & + & + & + & - & + \\
\hline Stigmatella aurantiaca M340 & $\mathrm{Sp}$ & + & - & + & + & + & + & + \\
\hline Stigmatella "cylindrica" M342 & $\mathrm{Sp}$ & + & - & + & + & - & + & + \\
\hline Stigmatella "media" M84 & $\mathrm{Sp}$ & + & - & + & + & + & - & + \\
\hline Stigmatella "media" M85 & $\mathrm{Sp}$ & + & - & + & + & + & + & + \\
\hline Stigmatella "media" M34 & $\mathrm{Sp}$ & + & - & + & + & + & + & + \\
\hline Stigmatella "media" M15 (ATCC 25190) & $\mathrm{Sp}$ & + & - & + & + & + & + & + \\
\hline Stigmatella erecta M26 (ATCC 25191) & $\mathrm{Sp}$ & + & - & + & + & + & + & + \\
\hline Stigmatella erecta M27 (ATCC 25192) & $\mathrm{Sp}$ & + & - & + & + & + & + & + \\
\hline Podangium erectum $\mathrm{M} 162$ & $\mathrm{Sp}$ & + & - & + & + & + & - & + \\
\hline Chondromyces crocatus M38 (ATCC 25193) & $\mathrm{SpE}$ & - & + & - & - & - & - & - \\
\hline Chondromyces crocatus M204 & $\mathrm{SpE}$ & - & + & - & - & - & - & - \\
\hline Chondromyces crocatus M1 20 & $\mathrm{SpE}$ & - & + & - & - & - & - & - \\
\hline Chondromyces apiculatus M6 & $\mathrm{SpE}$ & - & + & - & - & - & - & - \\
\hline Chondromyces apiculatus M36 & $\mathrm{SpE}$ & - & + & - & - & - & - & - \\
\hline Chondromyces pediculatus M118 & $\mathrm{SpE}$ & & + & - & & & & \\
\hline
\end{tabular}

Myxospores (Fig. 2) lack capsules and differ little from vegetative cells except for the presence of conspicuous refractile granules at one or both ends, 1.0 to $1.3 \mu \mathrm{m}$ by 3 to $6 \mu \mathrm{m}$.

Vegetative colonies on most media are initially translucent, almost colorless, later becoming yellowish-orange, and heaped at the periphery to form a "front" which is particularly conspicuous in contact with masses of living eubacteria. The underlying agar is pitted, eroded, and penetrated by columns of vegetative cells. Congo red is not adsorbed.

Growth on ECM agar (13) is poor with lysis generally limited to the immediate area of the colony. Lysis of living bacteria requires direct contact. Cultivated in pure culture on complex media containing enzymatically hydrolyzed protein and $\mathrm{Mg}^{+}$. Growth is stimulated by, and initially requires, an extract from eubacterial cells.

Nitrate is not reduced. Catalase and oxidase negative. Hydrolyzes starch, Tween 80 , indoxyl acetate, ribonucleic acid, deoxyribonucleic acid, gelatin, and casein. Does not hydrolyze urea, aesculin, or cellulose. Agar digestion not detected.

Aerobic.

Temperature range, 18 to $37 \mathrm{C}$; minimum, $18 \mathrm{C}$; optimum, 28 to $30 \mathrm{C}$.

Antibiotic sensitivity (discs): Resistant to neomycin $(10 \mu \mathrm{g})$, kanamycin $(10 \mu \mathrm{g})$, penicillin (10 units). Inhibited by streptomycin $(5 \mu \mathrm{g})$, tetracycline $(10 \mu \mathrm{g})$, chloramphenicol $(10 \mu \mathrm{g})$, and erythromycin $(5 \mu \mathrm{g})$.
Streptomycete-like odor produced is different from that of myxobacters with tapered cells.

Source and habitat: First observed on decayed melons from South Carolina. Later found by Thaxter (19) on old straw from Ceylon. Commonly found on dung in contact with soil, on bacterial streaks inoculated with soil, or on bark.

Neotype: Acc. no. 601, Thaxter collection, Farlow Herbarium, Harvard University.

Reference strain: Windsor M38 (ATCC 25193). 405.

Chondromyces apiculatus Thaxter 1897,

Vegetative rods are cylindrical with blunt, rounded ends, 1.1 to $1.4 \mu \mathrm{m}$ by 3 to $14 \mu \mathrm{m}$.

Sporangia (Fig. 6) straw-colored to bright orange or brownish-orange, variable in form and size, cylindrical to broadly turnip-shaped, 25 to $40 \mu \mathrm{m}$ by 35 to $50 \mu \mathrm{m}$, with colorless, pointed, frequently branched, apical appendages up to $35 \mu \mathrm{m}$ long. Pedicels absent or up to $30 \mu \mathrm{m}$ long, colorless. Sporangia borne in spherical clusters of 60 or more, although usually fewer in number than in C. crocatus. Stalk seldom branched, up to $700 \mu \mathrm{m}$ in height, diameter of 15 to $40 \mu \mathrm{m}$, longitudinally striated, tunnelled, and without internal cells. Forms without stalks, with basally fused sporangia, or with large, irregular, solitary sporangia are common. Secondary fruiting body formation as in $C$. crocatus or sporangium formation at tips of appendages is often observed. 
Myxospores similar to vegetative cells, 1.0 to $1.3 \mu \mathrm{m}$ by 3 to $6 \mu \mathrm{m}$ (Fig. 7 ).

In all other characteristics, it is identical to C. crocatus.

Source and habitat: Originally isolated from antelope dung from Liberia. Commonly observed on rabbit dung in contact with soil.

Guanine plus cytosine content is 69.3 moles per cent by $T_{m}$ determination.

Type: Acc. no. 4481, Thaxter Herbarium, Harvard University. 410.

Chondromyces pediculatus Thaxter 1904,

Vegetative cells cylindrical with blunt, rounded ends, 1.1 to $1.3 \mu \mathrm{m}$ by 3 to $16 \mu \mathrm{m}$.

Sporangia (Fig. 8) pale-yellow to orange, when dry orange-red, nearly spherical to long cylindrical, club-shaped or pyriform, usually broader and truncate at distal end, surface rough, 25 to $40 \mu \mathrm{m}$ by 35 to $60 \mu \mathrm{m}$. Borne in groups up to 60 in umbel-shaped heads on slender pedicels 20 to $40 \mu \mathrm{m}$ long. Stalk unbranched, up to $750 \mu \mathrm{m}$ in height, straited, sometimes twisted, colorless initially, becoming orange to brown when dry.

Myxospores lack capsules, resemble vegetative cells, 1.0 to $1.2 \mu \mathrm{m}$ by 3 to $7 \mu \mathrm{m}$ (Fig. 9).

Vegetative colonies orange to reddish-orange and resembling those of $C$. crocatus. Congo red is not adsorbed.

Cultivated on dung pellet agar and living bacteria. Growth is slow. Obtained once in pure culture on Escherichia coli extract-enriched Casitone $-\mathrm{Mg}^{++}$agar.

Cellulose is not hydrolyzed. Urease negative.

Source and habitat: Originally isolated on goose dung from South Carolina. Obtained on rabbit dung in contact with soil.

Type: Acc. no. 4524, Thaxter collection, Farlow Herbarium, Harvard University. 410 .

Chondromyces catenulatus Thaxter 1904,

Rods in rising spore mass, 1.0 to $1.3 \mu \mathrm{m}$ by 4 to $6 \mu \mathrm{m}$. Cells in vegetative colonies not described.

Sporangia (Fig. 4) light-yellow to orange, fusiform, long elliptical or irregular in shape, dimensions $18 \mu \mathrm{m}$ by 20 to $50 \mu \mathrm{m}$, united in chains up to $300 \mu \mathrm{m}$ long which may be branched once or twice. Sporangia separated by shrivelled, membranous isthmuses. Stalk simple, orange to rust-colored, up to $400 \mu \mathrm{m}$ in height, broad at base, tapering above, and several times cleft into swollen, tapering parts, each bearing one or several sporangial chains.
Myxospores are nonrefractile cylindrical rods with blunt, rounded ends, 1.2 to $1.4 \mu \mathrm{m}$ by 3 to $6 \mu \mathrm{m}$ (Fig. 5).

Cultivated only on original source, not reported in pure culture.

Source and habitat: Decaying poplar wood from New Hampshire.

Type: Acc. no. 4517, Thaxter collection, Farlow Herbarium, Harvard University. 861.

Chondromyces lanuginosus Kofler 1913,

[Objective synonym: Synangium lanuginosus (Kofler) Jahn 1924, 79.]

[Subjective synonyms: Chondromyces thaxteri Faull 1916, 226 and Synangium thaxteri (Faull) Jahn 1924, 79.]

Vegetative cells cylindrical with blunt, rounded ends 0.9 to $1.0 \mu \mathrm{m}$ by 3 to $8 \mu \mathrm{m}$.

Sporangia (Fig. 10) fused at their bases to form discoid or nearly spherical clusters containing up to 80 sporangia each with an apical tuft of hairs. Diameter of clusters variable ( 40 to $250 \mu \mathrm{m})$ as is the length of the apical hairs (7 to $30 \mu \mathrm{m}$ ). Stalks simple or occasionally branched, bearing from 1 to 30 clusters. Sporangia initially white changing to yellow, light-pink, and eventually orange. Stalks are at first colorless but become yellow. Sometimes the sporangial clusters give rise to secondary stalks which are thinner than the primary ones and which are tipped with smaller clusters.

Myxospores do not differ from vegetative cells, only slightly smaller, $0.6 \mu \mathrm{m}$ to 1.0 by 2.6 $\mu \mathrm{m}$.

Cultivation: Grown in laboratory culture on hay (Krzemieniewska and Krzemieniewski 1946, 37). Pure cultures not obtained.

Source and habitat: Found on the dung of herbivores in Canada (Faull 1916, 226) and Austria (Kofler 1913, 861); also found in soil in Poland (Krzemieniewska and Krzemieniewski 1946, 37).

Neotype: Acc. no. 4494 collected by J. H. Faull, Thaxter collection, Farlow Herbarium, Harvard University.

\section{Species incertae sedis}

Chondromyces sessilis Thaxter 1904, 411. Vegetative rods not described.

Sporangia (Fig. 11a,b) yellow to reddishorange, forming a sessile rosette or tuft on the substrate without a clearly differentiated stalk, although a poorly developed stalk is said occasionally to occur.

Sporangia quite variable in shape, irregularly and broadly fusiform, often subapiculate, with 
a wrinkled surface, variable in size, coherent at base or more or less completely confluent in irregular masses. Dimensions of sporangia, 18 to $35 \mu \mathrm{m}$ by 25 to $75 \mu \mathrm{m}$; dimensions of rosettes, 100 to $250 \mu \mathrm{m}$.

Myxospores are cylindrical with blunt, rounded ends, 0.8 to $1.0 \mu \mathrm{m}$ by 3 to $5 \mu \mathrm{m}$ (Fig. 12).

Source: Rotten wood from Florida. Cultivation not reported. Observed only on natural substrate.

Type: Acc. no. 4505, Thaxter collection, Farlow Herbarium, Harvard University.

Stigmatella Berkeley and Curtis.

The distinguishing features of species of Stigmatella employed by the Krzemieniewskis (8-11) seemed arbitrary and not always consistent. However, it was possible on the basis of their descriptions and of the appearance of our isolates on the natural substrates on which they were first encountered to assign tentatively each of our isolates to one of the four presently recognized (Bergey's
Manual, 7th ed.) species of Stigmatella. Table 2 summarizes the characteristics used by Krzemieniewska and Krzemieniewski to distinguish the species and permits a comparison with those of our isolates. It will be noted that great emphasis is placed on cyst shape, size, color, and the presence or absence of pedicels. The Krzemieniewskis were not very specific about the media or substrates employed, and there is no indication that they observed pure cultures. However, both the nature of the substrate and the presence of contaminants (especially molds) can have a profound effect on precisely those characteristics that the Krzemieniewskis emphasized.

It was not surprising, therefore, that there were differences (Table 1) among the pure cultures identified as Stigmatella aurantiaca, $S$. media, and $S$. cylindrica in cultural characteristics, fruiting bodies, and biochemical properties; these were trivial, however, and in any case uncorrelated with their "species" assignments. On the basis of these results, we

TABLE 2. Comparison of isolates of Stigmatella with original descriptions

\begin{tabular}{|c|c|c|c|c|}
\hline Organism $^{a}$ & $\begin{array}{l}\text { Color of mature } \\
\text { sporangia }\end{array}$ & $\begin{array}{l}\text { Shape of } \\
\text { sporangia }\end{array}$ & $\begin{array}{l}\text { Sporangial } \\
\text { dimensions }\end{array}$ & Pedicels \\
\hline $\begin{array}{l}\text { S. aurantiaca } \\
\text { (11) }\end{array}$ & $\begin{array}{l}\text { Orange-red to } \\
\text { yellow-brown }\end{array}$ & $\begin{array}{l}\text { Almost spherical } \\
\text { or elongated }\end{array}$ & $\begin{array}{l}14-54 \times \\
24-72 \mu \mathrm{m}\end{array}$ & $\begin{array}{l}\text { Present or } \\
\text { absent }\end{array}$ \\
\hline M340 & Orange-red & Oval or spherical & $\begin{array}{l}13-40 \times \\
30-50 \mu \mathrm{m}\end{array}$ & Absent \\
\hline M341 & Orange & $\begin{array}{l}\text { Oval or nearly } \\
\text { spherical }\end{array}$ & $\begin{array}{l}20-30 \times \\
30-50 \mu \mathrm{m}\end{array}$ & Absent \\
\hline $\begin{array}{l}\text { S. "cylindrica" } \\
\text { (11) }\end{array}$ & $\begin{array}{l}\text { Brilliant orange } \\
\text { sometimes brownish }\end{array}$ & $\begin{array}{l}\text { Usually cylindrical } \\
\text { but often oval or } \\
\text { spherical }\end{array}$ & $\begin{array}{l}20-30 \times \\
90 \mu \mathrm{m}\end{array}$ & $30 \mu \mathrm{m}$ \\
\hline M342 & Orange & Cylindrical & $\begin{array}{l}20-30 \times \\
40-70 \mu \mathrm{m}\end{array}$ & $40 \mu \mathrm{m}$ \\
\hline$S$. “media” (10) & $\begin{array}{l}\text { Orange-red, reddish- } \\
\text { orange or light brown }\end{array}$ & $\begin{array}{l}\text { Variable, oval or } \\
\text { tapering to base }\end{array}$ & $\begin{array}{l}26-93 \times \\
24-78 \mu \mathrm{m}\end{array}$ & $40 \mu \mathrm{m}$ \\
\hline M84 & Bright orangish-red & Oval or spherical & $\begin{array}{l}25-40 \times \\
40-50 \mu \mathrm{m}\end{array}$ & $40 \mu \mathrm{m}$ \\
\hline M85 & Bright orange-red & Oval or spherical & $\begin{array}{l}25-40 \times \\
30-50 \mu \mathrm{m}\end{array}$ & $40 \mu \mathrm{m}$ \\
\hline S. brunneus (11) & $\begin{array}{l}\text { Dark chestnut-brown, } \\
\text { almost black }\end{array}$ & Spherical or oval & $\begin{array}{l}28-83 \times \\
37-102 \mu \mathrm{m}\end{array}$ & $\begin{array}{l}30 \mu \mathrm{m} \text { but } \\
\text { settling down }\end{array}$ \\
\hline M26 & $\begin{array}{l}\text { Dark chestnut-brown, } \\
\text { almost black }\end{array}$ & Spherical or oval & $\begin{array}{l}40-80 \times \\
30-50 \mu \mathrm{m}\end{array}$ & $\begin{array}{l}20-30 \mu \mathrm{m} \\
\text { settling }\end{array}$ \\
\hline M27 & Dark chestnut-brown & Spherical or oval & $\begin{array}{l}\text { Avg } 40 \times \\
55 \mu \mathrm{m}\end{array}$ & $\begin{array}{l}20-30 \mu \mathrm{m} \\
\text { settling }\end{array}$ \\
\hline
\end{tabular}

$a$ Numbers in parentheses refer to references. 
conclude that the diagnostic characteristics used by Krzemieniewska and Krzemieniewski to distinguish $S$. cylindrica and $S$. media fall well within the range of variation of $S$. aurantiaca, not only as observed among our isolates and in the Thaxter specimens but also as was previously described $(5,11,17,19)$. We conclude, therefore, that $S$. media and $S$. cylindrica are merely varieties of $S$. aurantiaca.

Reichenbach and Dworkin (17) previously stated the opinion that all of the "species" of Stigmatella are varieties of $S$. aurantiaca. We believe, however, that Stigmatella brunnea is sufficiently different morphologically to retain it as a separate species. We previously expressed the opinion (15) that $S$. brunnea and Podangium erectum are identical. Various authors have cited the close similarity between $P$. erectum and the stigmatellae and in fact the Krzemieniewskis (8) made special reference to the very close resemblance of $S$. brunnea to $P$. erectum. In the present study, isolate M162 was initially identified as $P$. erectum (9) because, when first observed on bark (Fig. 17), it had produced no chondromyces-type fruiting bodies and it appeared to be identical to the Thaxter herbarium specimens (Fig. 18). However, once obtained in pure culture, it was indistinguishable from our cultures of $S$. brunnea.

The name Cystobacter erectus Schroeter 1886 antedates Chondromyces brunneus Krzemieniewska and Krzemieniewski 1946, and the specific epithet erectus has priority over brunneus. Consequently, the name Stigmatella erecta (basonym: Cystobacter erectus Schroeter) is proposed for this organism. The characteristics distinguishing $S$. erecta from $S$. aurantiaca are the greater frequency of monosporangial fruiting bodies, the consistently dark color of the sporangia, the larger average size of the sporangia, and the "settling down" of the stalks at maturity of the former.

Thus, the genus Stigmatella is to be regarded as consisting of a range of closely related morphological types with the chondromyceslike $S$. aurantiaca at one extreme and $S$. erecta of the "Podangium" morphological type at the other.

Genus Stigmatella Berkeley and Curtis 1874, 97.

(Objective synonym: Polycephalum Kalchbrenner and Cooke 1880,22.)

Vegetative cells are rods with tapered ends.

Sporangia borne singly or in clusters on stalked fruiting bodies (the stalks often occurring in groups arising from a common hypothallus).
Myxospores are short, rigid, phase-dense or refractile rods surrounded by a definite slime capsule.

Vegetative colonies do not etch, erode, or penetrate agar media. Congo red is adsorbed.

The minimal nutritional requirements are not known, but the organism is easily cultivated on media containing enzymatically hydrolyzed protein.

Urea is usually hydrolyzed.

Aerobic.

Temperature range, 18 to $37 \mathrm{C}$; optimum $30 \mathrm{C}$.

Guanine plus cytosine content of species examined is 68.5 to 68.7 moles per cent by $T_{m}$ determination (16).

Type species: Stigmatella aurantiaca Berkeley and Curtis 1874, 97.

Descriptions of Species of Stigmatella

Stigmatella aurantiaca Berkeley and Curtis $1874,97$.

[Objective synonym: Chondromyces aurantiacus (Berkeley and Curtis) Thaxter 1892, 401 ].

Vegetative cells are rods with tapered ends, 0.6 to $1.0 \mu \mathrm{m}$ by 4 to $10 \mu \mathrm{m}$ (Fig. 15).

On bark (Fig. 14) sporangia are spherical, oval, pear-shaped, or cylindrical; yellowishorange to bright orange-red or reddish-brown; variable in size, 16 to $70 \mu \mathrm{m}$ by 25 to $102 \mu \mathrm{m}$. Pedicels may be absent at maturity; when present, they are up to $40 \mu \mathrm{m}$ long. Stalks up to $400 \mu \mathrm{m}$ long, usually unbranched, sometimes arising from a common origin in a fascicled arrangement, granular, not striated, of hardened slime containing some cells, colorless to the color of the sporangia. Morphology of the fruiting bodies is variable especially in culture; forms (Fig. 13) with very long (to $900 \mu \mathrm{m}$ ) and irregularly branched, white to orange stalks lacking sporangia or tipped by one or few sporangia are often observed on plain agar in the presence of microbial contaminants; archangium-like forms are also common. When induced on $\mathrm{Ca}^{+}$-water agar, the fruiting bodies bear one or few sporangia.

Microcysts, 0.9 to $2 \mu \mathrm{m}$ by 1.6 to $4.0 \mu \mathrm{m}$ (average $1.0 \mu \mathrm{m}$ by $2.8 \mu \mathrm{m}$; Fig. 16).

Vegetative colonies are thin, flat with numerous radiating and concentric ridges, edge more or less definite or thin, filamentous and poorly delimited, light yellow or flesh-colored, occasionally producing a yellowish or brownish discoloration of agar media. Orange aggregates often form in old cultures on $0.1 \%$ casitone or $E$. coli media, but fruiting bodies fail to develop. Continued laboratory cultivation 
yields variants which produce mucoid colonies but which are unable to form fruiting bodies.

Easily cultivated on agar or liquid media containing 0.1 to $0.2 \%$ hydrolyzed protein, starch, and $0.01 \mathrm{M} \mathrm{Mg}^{+}$or on agar media containing dead bacterial cells.

Nitrate is not reduced. Catalase positive, oxidase negative. Hydrolyzes starch (3 days), Tween 80, indoxyl acetate, ribonucleic acid, deoxyribonucleic acid, gelatin, casein, urea, and aesculin.

Aerobic.

Temperature range, 18 to $37 \mathrm{C}$; optimum, $30 \mathrm{C}$.

Optimum $p \mathrm{H} 7.0$ to 7.2 .

Antibiotic sensitivity (discs): Resistant to penicillin (10 units), sensitive to streptomycin (5 $\mu \mathrm{g})$, tetracycline $(10 \mu \mathrm{g})$, chloramphenicol $(10 \mu \mathrm{g})$, kanamycin $(10 \mu \mathrm{g})$, and erythromycin $(5 \mu \mathrm{g})$. Response to neomy cin is variable.

Source and habitat: Originally observed on lichen. Most commonly observed on bark kept in a moisture chamber. Also from soil inoculated on streaks of living bacteria on filter paper over water agar.

Guanine plus cytosine content is 68.5 to 68.7 moles per cent by $\mathrm{T}_{\mathrm{m}}$ determination.

Neotype strain: Windsor M 341.

Stigmatella erecta (Schroeter) comb. nov.

[Objective synonyms: Cystobacter erectus Schroeter 1886,170

Chondromyces erectus (Schroeter) Thaxter 1897,407 80.]

Podangium erectum (Schroeter) Jahn 1924,

[Subjective synonyms: Chondromyces aurantiacus var. frutescens Krzemieniewska and Krzemieniewski 1927, 91

Chondromyces brunneus Krzemieniewska and Krzemieniewski 1946, 44

Stigmatella brunnea (Krzemieniewska and Krzemieniewski) McCurdy 1969, 1460.]

Vegetative cells are slightly tapering, flexible rods, 0.7 to $0.8 \mu \mathrm{m}$ by 5 to $10 \mu \mathrm{m}$.

On bark the sporangia are spherical (Fig. 17, 18), oval or elongated, at first flesh-colored becoming orange-red and finally dark chestnutbrown or almost black at maturity, 30 to 90 $\mu \mathrm{m}$ by 35 to $140 \mu \mathrm{m}$. Sometimes (especially on rabbit dung) borne singly on opaque white, later yellowish, stalks arising in groups from a common hypothallus. In other forms, several sporangia are arranged in clusters on yellowishwhite to orange-red stalks. The sporangia may or may not be borne on pedicels. In both forms, the stalks (and pedicels) commonly wither, depositing the cysts on the substrate; thus, they appear sessile in masses of fifty to hundreds together. On rabbit dung pellets, the fruiting bodies may appear as archangium-like masses or coralloid accumulations of pinkishwhite or salmon-colored, finger-like projections without clear-cut delimitation of sporangia. The tips eventually turn dark brown, the remainder becoming yellowish-white. On $\mathrm{Ca}^{+}$-water-agar, fruiting bodies with one to four sporangia on sparingly branched stalks ( 30 to $50 \mu \mathrm{m}$ by 80 to $200 \mu \mathrm{m}$ ) are produced.

Microcysts are straight, curved or somewhat fusiform, short rigid, phase-dense or refractile rods, 0.8 to $1.5 \mu \mathrm{m}$ by 1.5 to $3.5 \mu \mathrm{m}$ (Fig. 19).

Vegetative colonies are at first thin and transparent, later yellow or light flesh-colored with numerous radiating ridges. The edge is thin and indefinite. Continued laboratory cultivation selects variants with yellow or orange mucoid colonies. In old cultures the swarm turns dark brown, and the surrounding medium also becomes darkened.

Easily cultivated on media containing enzymatically hydrolyzed protein, starch, 0.01 $\mathrm{M} \mathrm{Mg}^{+}$, and salts. Growth has also been obtained on a medium containing 17 amino acids, thiamine, $0.01 \mathrm{M} \mathrm{Mg}^{+}$, and starch (16). Strictly respiratory, utilizing complex amino acids as energy source.

Nitrate is not reduced. Catalase positive. Oxidase negative.

Hydrolyzes starch (3 days), Tween 80, indoxyl acetate, deoxyribonucleic acid, ribonucleic acid, gelatin, casein, urea, and aesculin.

Aerobic.

Temperature range, 18 to $37 \mathrm{C}$; optimum, 28 to $30 \mathrm{C}$.

Optimum $p \mathrm{H} 7.0$ to 7.2

Antibiotic sensitivity (discs): Resistant to penicillin (10 units), sensitive to streptomycin (5 $\mu \mathrm{g})$, tetracycline $(10 \mu \mathrm{g})$, chloramphenicol $(10 \mu \mathrm{g})$, kanamycin $(10 \mu \mathrm{g})$, and erythromycin $(5 \mu \mathrm{g})$. Response to neomycin is variable.

Source and habitat: Obtained on the dung of herbivores placed in contact with soil or bark incubated in a moist chamber.

Guanine plus cytosine content is 68.7 moles per cent by $\mathrm{T}_{\mathrm{m}}$ determination (16).

Neotype strain: Windsor M26 (ATCC 25191).

\section{ACKNOWLEDGMENT}

This investigation was supported by a National Research Council of Canada grant.

\section{LITERATURE CITED}

1. Berkeley, M. J., and Curtis. 1857. In M. J. Berkeley (ed.), Intr. Crypt. Bot., p. 1-604. H. Baillere, London. 
2. Berkeley, M. J., and Curtis. 1874. In M. J. Berkeley (ed.), Notices of the North American fungi. Grevillea 3:1-17.

3. Enderlein, G. 1924. Bemerkungen zur Systematik der Chondromyciden. Walter de Gruyter and Co., Berlin.

4. Faull, J. 1916. Chondromyces thaxteri, a new Myxobacterium. Bot. Gaz. 62: 226-232.

5. Jahn, E. 1924. Beitrage zur botanischen Protistologie. I. Die Polyangiden, p. 1-107. Gebrïder Borntraeger, Leipzig.

6. Kalchbrenner, C., and M. C. Cooke. 1880. South African Fungi. Grevillea 9:17-34.

7. Kofler, L. 1913. Die Myxobacterien der Umgebung von Wien. SB Akad. Wiss. Abt. I Wien 122:845-876.

8. Krzemieniewska, H., and S. Krzemieniewski. 1926. Miksobakterje Polski. Acta Soc. Bot. Pol. 4:1-54.

9. Krzemieniewska. H., and S. Krzemieniewski. 1927 Miksobakterje Pol. Uzupelnienie. Acta Soc. Bot. Pol. 5:79-98.

10. Krzemieniewska, H., and S. Krzemieniewski. 1930. Miksobakterje Polski. Cześó Trzecia. Acta Soc. Bot. Pol. 7:250-273.

11. Krzemieniewska, H., and S. Krzemieniewski. 1946. Myxobacteria of the species Chondromyces Berkeley and Curtis. Bull. Int. Acad. Cracovien (Acad. Pol. Sci.) Ser. B. Sci. Nat. $1: 31-48$.

12. McCurdy, H. D. 1968. Light and electron microscope studies on the fruiting bodies of Chondro- myces crocatus. Arch. Mikrobiol. 65:380-390.

13. McCurdy, H. D. 1969. Studies on the taxonomy of the Myxobacterales. I. Record of Canadian isolates and survey of methods. Can. J. Microbiol. 15:1453-1461.

14. McCurdy, H. D., Jr. 1970. Studies on the taxonomy of the Myxobacterales. II. Polyangium and the demise of the Sorangiaceae. Int. J. Syst. Bacteriol. 20:283-296.

15. McCurdy, H. D., and B. T. Khouw. 1969. Studies on Stigmatella brunnea. Can. J. Microbiol. 15:731-738.

16. McCurdy, H. D., and S. Wolf. 1967. Deoxyribonucleic acid base compositions of fruiting Myxobacterales. Can. J. Microbiol. 13:1707-1708.

17. Reichenbach, H., and M. Dworkin. 1969. Studies on Stigmatella aurantiaca (Myxobacterales) J. Gen. Microbiol. 58:3-14.

18. Schroeter, J. 1886. Pilze, in Cohn, Ferdinand, Kryptogamen-Flora von Schlesien. J. U. Kern. Breslau 3:1-814.

19. Thaxter, R. 1892. On the Myxobacteriaceae, a new order of Schizomycetes. Bot. Gaz. $17: 389-406$

20. Thaxter, R. 1897. Further observation on the Myxobacteriaceae. Bot. Gaz. 23:385-411.

21. Thaxter, R. 1904. Notes on the Myxobacteriaceae. Bot. Gaz. 37:405-416.

22. Zukal, H. 1896. Myxobotrys variabilis Zuk., als Repräsentant einer neuen MyxomycetenOrdnung. Ber. Deut. Bot. Ges. 14:340-347. 